\title{
Articles
}

\section{Maternal Chronic Depression Affects Love Styles: A Cohort Study in Southern Brazil}

\author{
Denise Müller Böhmª, Luciana de Avila Quevedo*a, Fabio Monteiro da Cunha Coelhob, \\ Luciano Dias Mattos de Souzaa, Mariana Bonati de Matosa, Jéssica Puchalski Trettima, \\ Carolina Coelho Scholla, Bárbara Borges Rubina ${ }^{a}$, Rochele Castellib, Mariane Lopez Molina ${ }^{\mathrm{c}}$, \\ Karen Amaral Tavares Pinheiro ${ }^{d}$, Ricardo Tavares Pinheiro ${ }^{a}$
}

[a] Health and Behavior Post-Graduation Program, Catholic University of Pelotas, Pelotas, Brazil. [b] Federal University of Pelotas, Pelotas, Brazil. [c] Educational Anhanguera-Rio Grande, City of Rio Grande, Brazil. [d] Federal University of Rio Grande, City of Rio Grande, Brazil.

\begin{abstract}
Given the importance that love has in individuals' lives, and considering that more specific studies about the relationship between depression and the way people love are lacking, the aim of the current study was to evaluate the effect of major depressive disorder (MDD) on "love styles." This study was nested in a cohort of adolescent mothers. Women were assessed for MDD at each point of assessment: during pregnancy (T1), at between 30 and 60 postpartum days (T2), and at approximately 30 postpartum months (T3), by using the Mini International Neuropsychiatric Interview (MINI PLUS) tool. The Love Attitudes Scale (LAS) was administered to assess the six love styles at T3. Logistic regression analyses were carried out to express the strength of depression on love styles. We found that chronic major depression had the largest effect on the love styles (low Eros, high Mania, and high Agape), followed by current major depression. However, the same association was not observed in the perinatal period. Thus, the assessment of love style is relevant as it seems that an MDD-related injury in maternal life is related to their attitudes about love and there could be possible harmful consequences of these attitudes to the mother and the whole family.
\end{abstract}

Keywords: depression, major depressive disorder, love, love styles, interpersonal relations, pregnancy, mothers, adolescent mothers

Interpersona, 2020, Vol. 14(2), 104-117, https://doi.org/10.5964/ijpr.v14i2.4497

Received: 2020-04-13. Accepted: 2020-06-10. Published (VoR): 2020-12-22.

*Corresponding author at: Health and Behavior Post-Graduation Program, Catholic University of Pelotas, Rua Gonçalves Chaves, 373, CentroPelotas, Rio Grande do Sul, Zip Code 96015-560-Brazil. E-mail: lu.quevedo@bol.com.br provided the original work is properly cited.

Major depressive disorder (MDD) is a common mental disorder and is a leading cause of disability (considering the years lost) worldwide. In addition, it is two to three times more common in women. The main characteristics of the MDD are sadness, loss of interest in activities and decreased energy, but also by loss of confidence and self-esteem, unjustified feeling of guilt, ideas of death and suicide, decreased concentration and sleep and appetite disturbances (Marcus, Yasamy, van Ommeren, Chisholm, \& Saxena, 2012). Another important issue is persistence and recurrence, which are common to the MDD (Hames, Hagan, \& Joiner, 2013). 
The consequences of MDD are extensive and these not only include the impacts on the way individuals feel and think but also the deleterious effects on interpersonal functioning and romantic relationships (Burke, 2003; Hames, Hagan, \& Joiner, 2013; Hammen \& Brennan, 2002; Vujeva \& Furman, 2011). When suffering from MDD, people tend to present insecure interpersonal behavior patterns and are less likely to elicit positive social interactions (Burke, 2003; Gadassi, Mor, \& Rafaeli, 2011; Hames et al., 2013; Hammen, 2006). Sadness, loss of interest, and feelings of worthlessness/self-blame were all identified as symptoms that severely impair close relationships (Fried \& Nesse, 2014). MDD has been found to be associated with lower empathic accuracy and poor romantic relationship quality, including the amount of conflict and quality of problem solving (Frizzo, Brys, Lopes, \& Piccinini, 2010; Gadassi et al., 2011; Hames et al., 2013). Moreover, it is known that being in love seems to be challenging and daunting for adolescents and young adults (Bajoghli et al., 2014; Furman, 2002); therefore, these interpersonal relationships of a new mother, especially the relationship with her partner, usually suffer, for example, in terms of relationship satisfaction and privacy as a couple (Frizzo et al., 2010; Mortensen, Torsheim, Melkevik, \& Thuen, 2012). Considering this scenario, young mothers who are in their adolescence/emerging adulthood and suffering from MDD are probably at risk of portraying love in a more pathological way, since the interpersonal behavioral patterns of those suffering from MDD and symptoms such as sadness, loss of interest, and feelings of worthless/self- blame can severely impair close relationships.

According to Reis and Aron (2008), the love can be understood as the desire to enter, to maintain or to expand a continuous close relationship with another person. It is a sophisticated set of psychological devices that perform different functions in applicable contexts (Buss, 2006). Shiramizu and Lopes (2013) propose that love "includes selected feelings and thoughts throughout our evolutionary history that favored the bonding of partners, promoting an approach and a different investment of time and attention between them, which may vary according to ecological, social and cultural conditions". This understanding of love certainly does not cover all definitions on the subject, but it appears as a very comprehensive description on the basis that it has not been studied on the subject.

Lee (1977) developed a typology considering six love styles. On the basis of this typology, Hendrick and Hendrick (1986) created the Love Attitudes Scale (LAS) to measure the love styles characterized as follows: Eros - strong physical attraction, emotional intensity, a preferred physical appearance, and a sense of inevitability of the relationship. Ludus - love is a game to be played with a diverse set of patterns over time. Deception of the partner and lack of disclosure about self and other partners are prime attributes of Ludus. Storge - this takes love as friendship; it is quiet and companionate. Storge has sometimes been dubbed "love by evolution" rather than "love by revolution." Pragma - love is a shopping list of desired attributes (e.g., fitting into the family and good parent). Mania - this might be called "symptom love," and is similar to pathological love (Sophia et al., 2009). Mania is intense, alternating between ecstasy and agony. Agape - this love style is sacrificial, placing the love person's welfare above one's own.

The authors of the LAS consider that love styles seem to be both personality traits and flexible attitudes. Their theoretical approach maintains that everyone is, at a given time, located on each of the dimensions. Constitutional differences may tend to sustain one (or more) dimension, but they are changeable by experience (e.g., the interaction with the partner, the social network) and could present variations over time (Hendrick \& Hendrick, 2006). 
Although MDD has been associated with damage in interpersonal relationships, there is still a lack of evidence in the literature regarding the association of MDD, and mainly, its chronicity, with love styles. Considering the role that love has in an individuals' life, the fact that love styles are changeable, and major depressive episodes (which could bring harm to interpersonal and romantic relationships), the present study aimed to verify the effect of major depressive episodes on the love styles of young mothers, from the gestational period to 30 months of life of their children. The hypothesis tested in this study is that women diagnosed with MDD during the study - and especially those who presented chronically - tend to exhibit love styles pathologically or in an undesirable and unsuitable way.

\section{Method}

\section{Study Design}

This study was conducted with a cohort of adolescent mothers in the urban area of Pelotas, a city located in the Brazilian state of Rio Grande do Sul. The overall study intends to evaluate and follow the mental health of adolescent mothers and the overall development of their child.

\section{Participants}

Between October 2009 and March 2011, the participants were recruited from 47 primary healthcare units and three obstetric ambulatory care units that are part of the National Public Health System. All pregnant adolescents (15 to 19 years old) who were enrolled in a prenatal program of the municipal health department were asked to participate in the study. At the time of the present study, the sample was calculated according to prevalence of MDD in pregnant adolescents and its impact on the development of the child, resulting in a total of 544 participants. Figure 1 shows the diagram flow of this study. 


\section{STEP 1:}

Weekly visits to the Health Department to detect and update the sample

Informed consent

Home interview scheduling

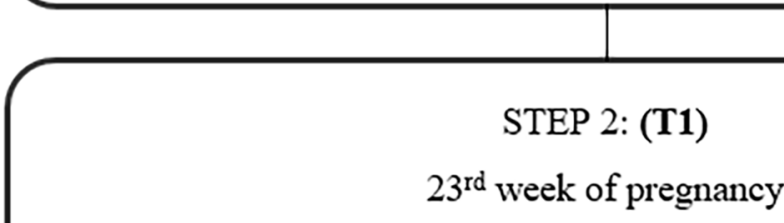

Home interview and application of instruments

STEP 3: (T2)

Between 30 and 60 days after birth

Return home for further interviews and application of instruments

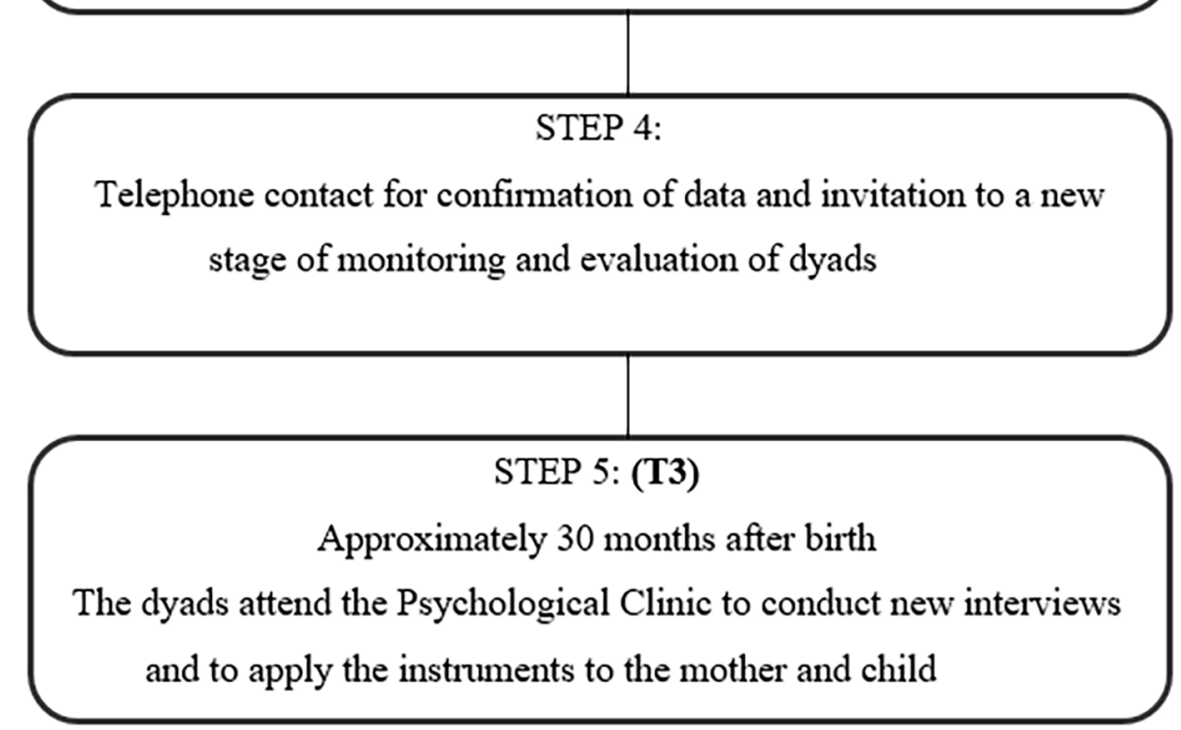

Figure 1. Diagram flow.

\section{Measures}

\section{Major Depressive Disorder}

A validated Portuguese version of the Mini International Neuropsychiatric Interview (MINI PLUS; Amorim, 2000) was used during pregnancy (Time 1 - T1); between 30 and 60 days postpartum (Time 2 - T2); and at approximately 30 months postpartum (Time 3 - T3). The instrument comprises a short structured interview with adequate validity and reliability to assess current MDD according to DSM-IV and ICD-10 criteria in less time than other diagnostic interviews, intended for use in clinical practice and research. The interviews were 
conducted by previously trained psychologists. The MDD variables were categorized as: "never" (included mothers who had not been diagnosed with major depressive disorder at any time during the study - neither in T1 nor T2 nor T3); "perinatal" - period defined as from conception to 1 year after birth (included mothers who were diagnosed with major depressive disorder during pregnancy - T1 - and or in the postpartum period - T2); "current" (mothers who presented major depressive disorder in the final stage of the study - T3) and "chronic" (mothers who were diagnosed with major depressive disorder in the perinatal and current period - T1 and/or T2 and T3).

\section{Love Styles}

A Brazilian validated version of the LAS (Berti et al., 2011) was administered. The used scale build by Hendrick et al. (1998), assesses the six love styles suggested by Lee (1977) and comprises 24 questions, separated into six corresponding subscales, with answers ranging from 1 to 5 . Cronbach's alpha reliabilities for all six subscales in the Brazilian sample were generically acceptable: Eros (.741), Storge (.898), Pragma (.648), Mania (.876), and Agape (.881) with the exception of Ludus (.448).

Analyses were conducted by determining the lowest or highest tertile of each love style that hypothetically embodies the "pathologic lovers," based on the characteristics of each love style and on prior research. Love style variables were transformed in dichotomous variables in which one-third of every variable represents the most pathological or undesirable pattern of love as follows: low Eros (low sexual attraction, low complicity, and low emotional intensity); high Ludus (very low commitment, high game-playing, and big lack of self disclosure); low Storge (low friendship); high Pragma (very low emotional, too selfish); high Mania (very obsessive, selfcentering and impulsive, high humor fluctuation, and high agony feelings associated with pathological love); and high Agape (too self regardless, low attention in self needs, and high level of sacrifice).

Participants answered the questions, taking into account their current or last romantic relationship.

\section{Socio-Demographic Data}

A self-report questionnaire was used to obtain data related to age, marital status, education, and socioeconomic status. Age was dichotomized into adolescent (ages 15 to 19) according to the World Health Organization (WHO; WHO, 2014), and emerging adulthood (ages 20 to 23) terminology borrowed from Arnett (2000). Marital status was categorized as living or not with a partner. Education (years of study) was grouped into four categories: less than 5 years, between 5 and 8 years, between 8 and 11 years, and between 11 and 14 years. Socioeconomic status was measured according to the Economic Classification for Brazil, from the Brazilian Association of Population Survey Companies (ABEP; ABEP, 2009), and ranked from the highest income level $(A)$ to the lowest $(E)$, with the levels then grouped into three categories: $A / B, C$, and $D / E$.

Statistical analyses were conducted using simple frequencies to characterize the sample and demonstrate the distribution of major depressive episodes as well as love styles. Bivariate analysis was used to establish associations between major depressive episodes, other variables of interest, and love styles. Further, logistic regression analyses were carried out to express the strength of depression over love styles, controlling for possible confounders. SPSS (Version 21.0) for Windows was used for the statistical analysis. 


\section{Procedure}

After the identification of the potential participants from the healthcare units, pregnant adolescents and their parents were contacted via telephone. In case of agreement to participate in the study, an appointment was made for a home interview. Then, a written informed consent was obtained, and if they were younger than 18 years old, permission and informed consent was requested from their parents.

Three interviews were conducted: during pregnancy (T1), with a mean gestational age of 23 weeks; between 30 and 60 days postpartum (T2); and at approximately 30 months postpartum (T3). T1 and T2 interviews were conducted in home visits, when instruments for the mental health assessment (including the MINI PLUS) and socio-demographic data were collected. The present study (T3) was conducted in the Psychological Clinic of the Catholic University of Pelotas, when - in addition to the tools previously used - the LAS was also administered.

\section{Results}

Of the initial 544 young mothers with a 30-month post-partum follow-up, 540 (99\%) completed the demographics questions, 502 (93\%) completed the diagnostic assessment for MDD, and the missings of the love styles variables is indicated in the Table 1. Their mean age was 20.1 years ( $S D \pm 1.5$ ); $39 \%$ had studied for between 5 and 8 years; $69 \%$ were inhered to $C$ socioeconomic status; and $55 \%$ were living with a partner. The prevalence of MDD in the perinatal, current, and chronic periods were $10 \%, 19 \%$, and $13 \%$, respectively (Table 1 ).

In a bivariate analysis, low Eros was associated with socioeconomic status $D / E(p=.009)$, living with a partner $(p<.001)$, and the presence of major depressive episode, in the current period and chronically $(p=.003)$. high Ludus $(p=.004)$ and low Storge $(p=.014)$ were related to not living with a partner. High Pragma had an association with low education $(p=.019)$, while high Mania was associated with low education $(p<.001)$, and major depressive episodes chronicity $(p \leq .001)$. High Agape was associated with living with a partner $(p$ $=.001$ ), and there was a presence of major depressive episodes in the perinatal, current, and chronic periods of the episodes $(p=.038$; Table 2$)$.

After adjusting for possible confounding variables, low Eros was still related with socioeconomic status, not living with a partner, and the presence of current and chronic major depressive episodes. Mothers from socioeconomic status D/E were 7.9 times $(95 \% \mathrm{Cl}[3.1,20.6])$ more likely to present low Eros when compared with mothers from socioeconomic status A/B. Women who did not live with their partner were 4.9 times $(95 \%$ $\mathrm{Cl}[3.0,7.9])$ more likely to show low Eros in relation to those who did. Those who were diagnosed with current major depressive episodes were 2.1 times (95\% $\mathrm{Cl}[1.2,3.8])$ more likely to be in the low Eros group than women who had never been diagnosed with major depressive episodes; those who presented chronic episodes were 2.6 times $(95 \% \mathrm{Cl}[1.3,5.1])$ more likely to show low Eros than those who never had any major depressive episodes.

Ludus and Storge remained associated with not living with a partner $(p=.004$ and $p=.011$, respectively). Mothers who were not living with a partner were 1.7 times $(95 \% \mathrm{Cl}[1.2,2.5])$ more likely to exhibit high Ludus and 1.6 times $(95 \% \mathrm{Cl}[1.1,2.3])$ more likely to present low Storge. 
Table 1

Sample Characteristics

\begin{tabular}{|c|c|c|}
\hline Variable & $N$ & $\%$ \\
\hline \multicolumn{3}{|l|}{ Age } \\
\hline from 15 to 19 & 179 & $33.1 \%$ \\
\hline from 20 to 23 & 361 & $66.9 \%$ \\
\hline \multicolumn{3}{|l|}{ Education } \\
\hline Less than 5 years & 40 & $7.4 \%$ \\
\hline Between 5 and 8 years & 214 & $39.6 \%$ \\
\hline Between 8 and 11 years & 196 & $36.3 \%$ \\
\hline Between 11 and 14 years & 90 & $16.7 \%$ \\
\hline \multicolumn{3}{|l|}{ Socioeconomic status ${ }^{a}$} \\
\hline$A / B$ & 84 & $16.3 \%$ \\
\hline C & 357 & $69.5 \%$ \\
\hline $\mathrm{D} / \mathrm{E}$ & 73 & $14.2 \%$ \\
\hline \multicolumn{3}{|l|}{ Lives with partner } \\
\hline No & 249 & $46.1 \%$ \\
\hline Yes & 291 & $53.9 \%$ \\
\hline \multicolumn{3}{|l|}{ Low Eros ${ }^{a}$} \\
\hline No & 373 & $70.8 \%$ \\
\hline Yes & 154 & $29.2 \%$ \\
\hline \multicolumn{3}{|l|}{ High Ludus $^{a}$} \\
\hline No & 344 & $65.9 \%$ \\
\hline Yes & 178 & $34.1 \%$ \\
\hline \multicolumn{3}{|l|}{ Low Storge $^{a}$} \\
\hline No & 337 & $64.2 \%$ \\
\hline Yes & 188 & $35.8 \%$ \\
\hline \multicolumn{3}{|l|}{ High Pragma $^{a}$} \\
\hline No & 359 & $66.9 \%$ \\
\hline Yes & 178 & $33.1 \%$ \\
\hline \multicolumn{3}{|l|}{ High Mania $^{a}$} \\
\hline No & 361 & $68.5 \%$ \\
\hline Yes & 166 & $31.5 \%$ \\
\hline \multicolumn{3}{|l|}{ High Agape $^{a}$} \\
\hline No & 356 & $66.4 \%$ \\
\hline Yes & 180 & $33.6 \%$ \\
\hline \multicolumn{3}{|l|}{ Major depressive disorder ${ }^{a}$} \\
\hline Never & 296 & $58.1 \%$ \\
\hline Perinatal & 50 & $9.9 \%$ \\
\hline Current & 96 & $18.9 \%$ \\
\hline Chronic & 60 & $13.2 \%$ \\
\hline Total & 540 & $100.0 \%$ \\
\hline
\end{tabular}

aariables with missing.

Pragma remained associated with education. Mothers who had studied for less than 5 years were 3.3 times $(95 \% \mathrm{Cl}[1.5,7.4])$ more likely to show high Pragma when compared with mothers with 11-14 years of education. 
Table 2

Bivariate Analysis Demonstrating the Association of Socioeconomic Variables and MDD With the Six Love Styles

\begin{tabular}{|c|c|c|c|c|c|c|}
\hline \multirow[b]{2}{*}{ Variable } & \multicolumn{6}{|c|}{$N(\%)$} \\
\hline & Low Eros & High Ludus & Low Storge & High Pragma & High Mania & High Agape \\
\hline Age ( $p$-value) & .784 & .419 & .461 & .463 & .124 & .612 \\
\hline from 15 to 19 & $49(28.2)$ & $65(36.7)$ & $58(33.3)$ & $59(33.0)$ & $64(36.2)$ & $57(31.8)$ \\
\hline from 20 to 23 & $105(29.7)$ & $113(32.8)$ & $130(37.0)$ & $131(36.6)$ & $102(29.1)$ & $123(34.5)$ \\
\hline Education ( $p$-value) & .078 & .122 & .069 & .019 & .000 & .143 \\
\hline Less than 5 years & $16(42.1)$ & $11(29.7)$ & $9(24.3)$ & $19(48.7)$ & $18(47.4)$ & $16(42.1)$ \\
\hline Between 5 and 8 years & $50(23.8)$ & $82(40.2)$ & $65(31.3)$ & $76(35.8)$ & $84(40.2)$ & $80(37.9)$ \\
\hline Between 8 and 11 years & $61(32.1)$ & $57(29.8)$ & $78(41.1)$ & $62(31.8)$ & $46(24.1)$ & $59(30.1)$ \\
\hline Between 11 and 14 years & $26(29.5)$ & $27(30.3)$ & $36(40.4)$ & $20(22.2)$ & $17(19.3)$ & $25(27.8)$ \\
\hline Socioeconomic status ( $p$-value) & .009 & .939 & .473 & .423 & .072 & .386 \\
\hline$A / B$ & $14(17.1)$ & $27(32.9)$ & $25(30.5)$ & $23(27.7)$ & $17(20.7)$ & $26(31.0)$ \\
\hline $\mathrm{C}$ & $102(29.4)$ & $120(34.9)$ & $129(37.3)$ & $121(34.2)$ & $116(33.4)$ & $127(36.1)$ \\
\hline $\mathrm{D} / \mathrm{E}$ & $28(39.4)$ & $24(33.8)$ & $27(38.6)$ & $27(37.0)$ & $20(28.2)$ & $21(28.8)$ \\
\hline Lives with partner ( $p$-value) & .000 & .004 & .014 & .285 & 1.000 & .001 \\
\hline No & $104(43.3)$ & $97(40.9)$ & $99(41.8)$ & $88(35.8)$ & $77(31.6)$ & $63(25.7)$ \\
\hline Yes & $49(17.1)$ & $81(28.5)$ & $89(31.0)$ & $90(31.0)$ & $88(31.2)$ & $117(40.3)$ \\
\hline Major depressive disorder ( $p$-value) & .003 & .831 & .887 & .970 & .000 & .038 \\
\hline Never & $69(24.0)$ & $102(34.9)$ & $106(36.5)$ & $96(32.7)$ & $71(24.9)$ & $80(27.3)$ \\
\hline Perinatal & 18 (33.3) & 15 (29.5) & $18(35.6)$ & $18(35.6)$ & $16(31,58)$ & $20(40.0)$ \\
\hline Current & $38(42.0)$ & $32(36.3)$ & $37(40.7)$ & 31 (32.6) & 37 (39.3) & 38 (39.5) \\
\hline Chronic & $28(41.7)$ & $23(38.2)$ & $22(35.1)$ & $23(35.0)$ & $35(52.5)$ & $27(41.4)$ \\
\hline Total & $154(17.3)$ & $178(34.1)$ & $188(35.8)$ & $178(33.1)$ & $166(31.5)$ & $180(33.6)$ \\
\hline
\end{tabular}

Note. $p$-values correspond to chi-square tests comparing the proportions for each love style between the categories of the independent variables.

Mania maintained an association with age, education, and the presence of depressive episodes. The youngest mothers were 1.4 times $(95 \% \mathrm{Cl}[1.0,2.0])$ more likely to disclose high Mania in relation to the oldest mothers. Regarding education, women who studied for few years were 4.8 times $(95 \% \mathrm{Cl}[1.8,12.8])$ more likely to present high Mania than those who had a higher education. Moreover, mothers with chronic depressive episodes were 2.7 times $(95 \% \mathrm{Cl}[1.4,5.1])$ more likely to show high Mania when compared to mothers who had never had a major depressive episode.

Finally, with respect to Agape, mothers who were currently experiencing a depressive episode were 1.8 times $(95 \% \mathrm{Cl}[1.1,3.2])$ more likely to present high Agape. Those mothers who suffered from chronic depressive episodes were 1.9 times $(95 \% \mathrm{Cl}[1.1,3.2])$ more likely to show high Agape in comparison to those who have never had a major depressive episode (Table 3). 
Table 3

Adjusted Analysis Demonstrating the Impact of Socioeconomic Variables and MDD on the Six Love Styles

\begin{tabular}{|c|c|c|c|c|c|c|}
\hline \multirow[b]{2}{*}{ Variable } & \multicolumn{6}{|c|}{ PR $[95 \% \mathrm{Cl}]$} \\
\hline & Low Eros & High Ludus & Low Storge & High Pragma & High Mania & High Agape \\
\hline Age ( $p$-value) & - & - & - & - & .021 & - \\
\hline from 15 to 19 & - & - & - & - & $1.4[1.0,2.0]$ & - \\
\hline from 20 to 23 & - & - & - & - & 1.000 & - \\
\hline Education ( $p$-value) & .083 & .124 & .071 & .021 & .002 & .145 \\
\hline Less than 5 years & $1.7[0.8,3.8]$ & 1.000 & 1.000 & $3.3[1.5,7.4]$ & $4.8[1.8,12.8]$ & $1.9[0.8,4.2]$ \\
\hline Between 5 and 8 years & $0.7[0.4,1.3]$ & $1.6[0.7,3.4]$ & $1.4[0.6,3.2]$ & $1.9[1.1,3.5]$ & $3.0[1.5,6.0]$ & $1.6[0.9,2.7]$ \\
\hline Between 8 and 11 years & $1.1[0.7,2.0]$ & $1.0[0.5,2.2]$ & $2.2[0.9,4.8]$ & $1.6[0.9,2.9]$ & $1.5[0.7,3.1]$ & $1.1[0.6,1.9]$ \\
\hline Between 11 and 14 years & 1.000 & $1.0[0.4,2.4]$ & $2.1[0.9,5.0]$ & 1.000 & 1.000 & 1.000 \\
\hline Socioeconomic status ( $p$-value) & .000 & - & - & - & .203 & - \\
\hline$A / B$ & 1.000 & - & - & - & 1.000 & - \\
\hline C & $3.5[1.7,7.2]$ & - & - & - & $1.5[0.8,2.9]$ & - \\
\hline $\mathrm{D} / \mathrm{E}$ & $7.9[3.1,20.6]$ & - & - & - & $0.9[0.4,2.4]$ & - \\
\hline Lives with partner ( $p$-value) & .000 & .004 & .011 & - & - & .001 \\
\hline No & $4.9[3.0,7.9]$ & $1.7[1.2,2.5]$ & $1.6[1.1,2.3]$ & - & - & 1.000 \\
\hline Yes & 1.000 & 1.000 & 1.000 & - & - & $1.9[1.3,3.0]$ \\
\hline Major depressive disorder ( $p$-value) & .012 & - & - & - & .004 & .037 \\
\hline Never & 1.000 & - & - & - & 1.000 & 1.000 \\
\hline Perinatal & $1.6[0.7,3.6]$ & - & - & - & $0.9[0.4,2.0]$ & $1.5[0.8,3.0]$ \\
\hline Current & $2.1[1.2,3.8]$ & - & - & - & $1.9[1.1,3.3]$ & $1.8[1.1,3.2]$ \\
\hline Chronic & $2.6[1.3,5.1]$ & - & - & - & $2.7[1.4,5.1]$ & $1.9[1.0,3.6]$ \\
\hline
\end{tabular}

Note. $p$-values correspond to logistic regression. $\mathrm{PR}=$ prevalance ratio.

\section{Discussion}

This study aimed to verify the effect of major depressive episodes on the romantic love styles of emerging adult mothers. Although the literature suggests that MDD impairs romantic relationships (Burke, 2003; Vujeva \& Furman, 2011), this cannot be affirmed in the present study because love styles were assessed only at the T3 stage. Therefore, appropriate statistical treatment of the data was applied and does not necessarily point to a causal relation between depression and love styles. Considering this, an inverse relationship is also possible in which the love styles trigger the depression.

We found that chronic major depression has the largest effect on love styles (low Eros, high Mania, and high Agape), followed by current major depression. However, the same relationship was not observed in the perinatal period, probably because women are more focused on the baby and the transition to motherhood during this period than on their romantic relationship. Moreover, perinatal depression seems to be a very specific form of depression, probably associated with changes in ovarian hormones, even though the underlying mechanisms need further explanations (Albert, 2015; Bloch, Daly, \& Rubinow, 2003).

Eros can be considered the healthiest love style. As explained by Levine, Aune, and Park (2006), people with high Eros scores may be able to maintain their relationships more easily and for longer if they increase contact, show tokens of affection, and demonstrate behavioral adaptations. Besides being characterized by strong physical attraction, high complicity, and emotional intensity (Hendrick \& Hendrick, 1986), Eros lovers commonly 
conduct their personal relationships in a warm and positive way and are shown to be content about life and work and show self-confidence in love (Lee, 1977). Thus, it is not surprising that low Eros scores matched with major depressive states, considering the common characteristics and the interpersonal processes on MDD such as low interest or pleasure from social interactions, isolation, extreme feelings of worthlessness or guilt (Hames et al., 2013).

On the opposite side of this are Mania and Agape, already found to be associated with pathological love in another study (Sophia et al., 2009) and associated with depression in the present research. Studies found that people with MDD tend to engage in excessive interpersonal feedback seeking behaviors, core beliefs reflecting insecurity in relationships, interpersonal dependency, and insecure attachment styles (Hames et al., 2013). Characteristics of a manic lover seem to present a similar direction, including loneliness, lack of friends, and lack of enjoyable work (Lee, 1977). Moreover, manic lovers are more likely to enact negative relational maintenance behaviors (Goodboy, Myers, \& Members of Investigating, 2010). This pattern can, in turn, possibly play an important role in the maintenance of the MDD, providing a feedback cycle of the disorder.

An important characteristic of MDD is the difficultly that the individual experiences in having positive attitudes toward themselves, as it explains part of Beck's (Beck, Rush, Shaw, \& Emery, 1979) cognitive triad, also known as the negative triad, that is a cognitive-therapeutic view of the three key elements of a person's belief system present in depression (negative view of oneself, environment and future; Pössel \& Pittard, 2016). High Agape scores (too self regardless, low attention to self needs, and high level of sacrifice) seem to be a symptom of MDD. It is likely that the focus on their lover's needs is used to take the focuses off their own suffering and needs. Furthermore, making sacrifices for their lover can dissemble worthlessness feelings. Thus, some damages to interpersonal and loving relationships related to the presence of MDD are evident.

The finding that mothers who were not living with a partner interestingly presented low Eros, high Ludus, and low Storge. Assuming that Eros and Storge are defined by commitment in relationships, and Ludus is defined by avoiding commitment, it seems this was a group (low Eros, high Ludus, and low Storge) for who is difficult to establish intimate relationships and maintain a partnership.

Another finding was that women who were inhered of low socioeconomic status presented low Eros. One possible explanation for this is that Eros-style love is very intense and the relationship has a very important place in the individuals' life, and financial difficulties can cause problems in personal relationships, particularly this love style, which demands a considering level of surrender.

Finally, it was verified that adolescent mothers presented high Mania, which can be related to the "storm and stress" period when unstable mood is common (Arnett, 1999). This association was not found in another study (Shulman \& Scharf, 2000), which identified Storge as more prevalent in the youngest group. Considering that romantic relationships can positively affect development and also place adolescents at risk of problems (Furman, 2002), the results call attention to the need to take their "love difficulties" seriously, as a potential risk for present and future mental health.

The results of this research need to be interpreted in the light of some limitations. First, as already mentioned, love style information was available only in the last period of the study. Evaluation of love styles at other points in the research could enrich analyses and ground a causal relation between variables. Another limitation was the lack of data regarding relationship characteristics, such as duration of the relationship, level of satisfaction, 
quality of interactions, and intensity of couple commitment. Some of these variables could moderate, in part, the relation between MDD and love styles and enhance the study, prompting a suggestion for future research.

\section{Conclusions}

Despite the limitations, this study contributes to the literature on mental health and romantic relationships, as the current literature is scarce. The results point to the importance of MDD, and especially its chronicity, in the relationship with love styles. Furthermore, this study extended the notion, observed in previous research (Gadassi et al., 2011; Zeigler-Hill, Britton, Holden, \& Besser, 2015), that people without positive attitudes toward themselves and their close relationships may have more pathological and unsuitable love interactions.

It seems that another injury related to MDD in maternal life impacts the way that the mothers act about love, and the consequences that a pathological pattern can bring to the relationship with the whole family. Thus, it is important to identify the love style in woman suffering from MDD, given the importance that love relationships have in an individual's life, and even more so in a young mother's life.

The healthier a woman's love, the healthier the interaction with her partner and, consequently, with her baby. Further, the healthier her interpersonal relations, the better her prognosis regarding major depression remission.

\section{Funding}

This research supprted by Fundação de Amparo à Pesquisa do Estado do Rio Grande do Sul (FAPERGS).

\section{Competing Interests}

The authors have declared that no competing interests exist.

\section{Acknowledgments}

The authors would like to thank the women who kindly participated in this study. We also would like to acknowledge the Fundação de Amparo à Pesquisa do Estado do Rio Grande do Sul (FAPERGS) for having supported this research. We also thank the Coordenação de Aperfeiçoamento de Pessoal de Nível Superior (Capes) and Conselho Nacional de Desenvolvimento Científico e Tecnológico (CNPq) for the scholarships avaiability.

\section{Ethical Approval}

Compliance with Ethical Standards: The present study was approved by the research ethics committee of the Catholic University of Pelotas. Confidentiality of data and care with information management were assured. The participants who screened positive for any psychiatric disorder or suicidal behavior were referred to the psychiatric clinic of the Catholic University of Pelotas. All procedures performed in studies involving human participants were in accordance with the ethical standards of the institutional research committee and with the 1964 Helsinki Declaration and its later amendments or comparable ethical standards. Informed consent was obtained from all individual adult participants included in the study; assent was obtained from children.

\section{References}

Albert, P. R. (2015). Why is depression more prevalent in women? Journal of Psychiatry \& Neuroscience, 40(4), $219-221$. https://doi.org/10.1503/jpn.150205 
Amorim, P. (2000). Mini International Neuropsychiatric Interview (MINI): validação de entrevista breve para diagnóstico de transtornos mentais. The British Journal of Psychiatry, 22, 106-115. https://doi.org/10.1590/S1516-44462000000300003

Arnett, J. J. (1999). Adolescent storm and stress, reconsidered. The American Psychologist, 54(5), 317-326. https://doi.org/10.1037/0003-066X.54.5.317

Arnett, J. J. (2000). Emerging adulthood: A theory of development from the late teens through the twenties. The American Psychologist, 55(5), 469-480. https://doi.org/10.1037/0003-066X.55.5.469

Bajoghli, H., Keshavarzi, Z., Mohammadi, M. R., Schmidt, N. B., Norton, P. J., Holsboer-Trachsler, E., \& Brand, S. (2014). "I love you more than I can stand!" - romantic love, symptoms of depression and anxiety, and sleep complaints are related among young adults. International Journal of Psychiatry in Clinical Practice, 18(3), 169-174. https://doi.org/10.3109/13651501.2014.902072

Beck, A. T., Rush, A. J., Shaw, B. F., \& Emery, G. (1979). Cognitive therapy of depression. New York, NY, USA: Guilford Press.

Berti, M. P., Zilberman, M. L., Sophia, E. C., Gorenstein, C., Pereira, A. P., Lorena, A., . . Tavares, H. (2011). Validação de escalas para avaliação do amor patológico. Archives of Clinical Psychiatry, 38, 135-138.

https://doi.org/10.1590/S0101-60832011000400004

Bloch, M., Daly, R. C., \& Rubinow, D. R. (2003). Endocrine factors in the etiology of postpartum depression. Comprehensive Psychiatry, 44(3), 234-246. https://doi.org/10.1016/S0010-440X(03)00034-8

Brazilian Association of Population Survey Companies. (2009). Critério de classificação econômica. Retrieved from http://www.abep.org/criterio-brasil

Burke, L. (2003). The impact of maternal depression on familial relationships. International Review of Psychiatry, 15(3), 243-255. https://doi.org/10.1080/0954026031000136866

Buss, D. M. (2006). The evolution of love. In R. J. Sternberg \& K. Weis (Eds.), The new psychology of love (pp. 65- 86). New Haven, CT, USA: Yale University Press.

Fried, E. I., \& Nesse, R. M. (2014). The impact of individual depressive symptoms on impairment of psychosocial functioning. PLOS ONE, 9(2), Article e90311. https://doi.org/10.1371/journal.pone.0090311

Frizzo, G. B., Brys, I., Lopes, R. C. S., \& Piccinini, C. A. (2010). Conjugalidade em contexto de depressão da esposa no final do primeiro ano de vida do bebê. Aletheia, 31, 66-81.

Furman, W. (2002). The emerging field of adolescent romantic relationships. Current Directions in Psychological Science, 11(5), 177-180. https://doi.org/10.1111/1467-8721.00195

Gadassi, R., Mor, N., \& Rafaeli, E. (2011). Depression and empathic accuracy in couples: An interpersonal model of gender differences in depression. Psychological Science, 22(8), 1033-1041. https://doi.org/10.1177/0956797611414728

Goodboy, A. K., Myers, S. A., \& Members of Investigating. (2010). Relational quality indicators and love styles as predictors of negative relational maintenance behaviors in romantic relationships. Communication Reports, 23(2), 65-78. https://doi.org/10.1080/08934215.2010.511397 
Hames, J. L., Hagan, C. R., \& Joiner, T. E. (2013). Interpersonal processes in depression. Annual Review of Clinical Psychology, 9, 355-377. https://doi.org/10.1146/annurev-clinpsy-050212-185553

Hammen, C. (2006). Stress generation in depression: Reflections on origins, research, and future directions. Journal of Clinical Psychology, 62(9), 1065-1082. https://doi.org/10.1002/jclp.20293

Hammen, C., \& Brennan, P. A. (2002). Interpersonal dysfunction in depressed women: Impairments independent of depressive symptoms. Journal of Affective Disorders, 72(2), 145-156. https://doi.org/10.1016/S0165-0327(01)00455-4

Hendrick, C., \& Hendrick, S. (1986). A theory and method of love. Journal of Personality and Social Psychology, 50(2), 392-402. https://doi.org/10.1037/0022-3514.50.2.392

Hendrick, C., \& Hendrick, S. S. (2006). Styles of romantic love. In R. J. Sternberg \& K. Weis (Eds.), The new psychology of love (pp. 149-170). Binghamton, NY, USA: Vail-Ballou Press.

Hendrick, C., Hendrick, S. S., \& Dicke, A. (1998). The Love Attitudes Scale: Short form. Journal of Social and Personal Relationships, 15(2), 147-159. https://doi.org/10.1177/0265407598152001

Lee, J. A. (1977). A typology of styles of loving. Personality and Social Psychology Bulletin, 3(2), 173-182. https://doi.org/10.1177/014616727700300204

Levine, T. R., Aune, K. S., \& Park, H. S. (2006). Love styles and communication in relationships: Partner preferences, initiation, and intensification. Communication Quarterly, 54(4), 465-486. https://doi.org/10.1080/01463370601036515

Marcus, M., Yasamy, M. T., van Ommeren, M., Chisholm, D., \& Saxena, S. (2012). Depression: A global public health concern. Retrieved from https://www.who.int/mental_health/management/depression/who_paper_depression_wfmh_2012.pdf

Mortensen, Ø., Torsheim, T., Melkevik, O., \& Thuen, F. (2012). Adding a baby to the equation. married and cohabiting women's relationship satisfaction in the transition to parenthood. Family Process, 51(1), 122-139.

https://doi.org/10.1111/j.1545-5300.2012.01384.x

Pössel, P., \& Pittard, C. (2016) Depressive cognitive triad. In V. Zeigler-Hill, \& T. Shackelford T (Eds.), Encyclopedia of personality and individual differences (pp. 1-2). Cham, Switzerland: Springer.

Reis, H. T., \& Aron, A. (2008). Love: What is it, why does it matter, and how does it operate? Perspectives on Psychological Science, 3, 80-86. https://doi.org/10.1111/j.1745-6916.2008.00065.x

Shiramizu, V. K. M., \& Lopes, F. A. (2013). A perspectiva evolucionista sobre relações românticas. Psicologia USP, 24(1), 55-76. https://doi.org/10.1590/S0103-65642013000100004

Shulman, S., \& Scharf, M. (2000). Adolescent romantic behaviors and perceptions: Age- and gender-related differences, and links with family and peer relationships. Journal of Research on Adolescence, 10(1), 99-118.

https://doi.org/10.1207/SJRA1001_5

Sophia, E. C., Tavares, H., Berti, M. P., Pereira, A. P., Lorena, A., Mello, C., . . Zilberman, M. L. (2009). Pathological love: Impulsivity, personality, and romantic relationship. CNS Spectrums, 14(5), 268-274.

https://doi.org/10.1017/S1092852900025438 
Vujeva, H. M., \& Furman, W. (2011). Depressive symptoms and romantic relationship qualities from adolescence through emerging adulthood: A longitudinal examination of influences. Journal of Clinical Child and Adolescent Psychology, 4O(1), 123-135. https://doi.org/10.1080/15374416.2011.533414

World Health Organization. (2014). Adolescent pregnancy. Retrieved from http://www.who.int/mediacentre/factsheets/fs364/en/

Zeigler-Hill, V., Britton, M., Holden, C. J., \& Besser, A. (2015). How will i love you? Self-esteem instability moderates the association between self-esteem level and romantic love styles. Self and Identity, 14(1), 118-134.

https://doi.org/10.1080/15298868.2014.960445 